\title{
TRAUMAS OF ROOTS AND EXTINCTION IN THE 20TH CENTURY LITERATURE OF EMPIRE: THE MIRROR PRINCIPLE IN MARGUERITE DURAS' INDIA CYCLE (1964-71) AND AHMED ALI'S TWILIGHT IN DELHI (1940)
}

\author{
Tadd Graham Fernée \\ New Bulgarian University, Sofia, Bulgaria
}

\begin{abstract}
This article comparatively analyses Marguerite Duras' India Cycle and Ahmed Ali's Twilight in Delhi. A Mirror Principle centres on 'emptiness', synthesising elements of Marxism and Buddhism. A new optic is created for understanding 1930s Indian nationalism, including Dalit and national leader Ambedkar, Tagorian "composite culture", Mohammed Iqbal, and Islam and gender in northern India. The Mirror Principle juxtaposes Heideggerian 'repetition' and Marxian 'dialectics' as divergent anti-colonial paths. Duras and Ali are linked by a common Proustian problematic of memory and ephemerality. They revolutionize the Proustian tradition to create a new literary genre in oneiric socialism. The article analyses trauma, in the French Resistance and the 1857 rebellion, and literary reconstructions of traditional roots in their wake, with differing nation-making ramifications.
\end{abstract}

Keywords: Marguerite Duras, Ahmed Ali, Indian nationalism, Islam, Marxism, Heideggerianism, Buddhism, Ambedkar, Tagore, French Resistance, colonialism, Proust

\section{Article history:}

Received: 25 April 2020;

Reviewed: 9 June 2020;

Accepted: 10 June 2020;

Published: 30 June 2020

Copyright (C) 2020 Tadd Graham Fernée

This open access article is published and distributed under a CC BY-NC 4.0 International License which permits non-commercial use, distribution, and reproduction in any medium, provided the original author and source are credited. Permissions beyond the scope of this license may be available at tfernee@hotmail.com. If you want to use the work commercially, you must first get the authors' permission.

Citation: Hoyte-West, A. (2020). Traumas of Roots and Extinction in the 20th Century Literature of Empire: The Mirror Principle in Marguerite Duras' India Cycle (1964-71) and Ahmed Ali's Twilight in Delhi (1940). English Studies at NBU, 6(1), 145-172. https:/ / doi.org/ 10.33919/ esnbu.20.1.7

Tadd Graham Fernée is part of the Department of Foreign Languages and Cultures of New Bulgarian University. He is a researcher for New York University, and the author of The Enlightenment and Violence: Modernity and Nation-Making (2014).

E-mail: tfernee@ hotmail.com 


\section{Indian Nationalism meets the French Resistance}

Marguerite Duras' (1914-1996) India Cycle comprises three novels, Le Ravissement de Lol V. Stein (1964), Le Vice-Consul (1966), and L'Amour (1971). Across the world, characters recur, emanating from the founding event opening Ravissement (alternately "abduction" and "holy rapture", a double meaning). At a French seaside ball, Michael Richardson publicly abandons his fiancée Lol, a nineteen-year-old bourgeois, for AnneMarie Stretter, the wife of the French Ambassador to India. This scene of banality has the strangeness of an alien abduction. Traumatized, Lol later marries an airplane factory owner, John Bedford, to forget. After ten years of obsessive compulsive disorder, Lol starts a secret life of voyeurism. The narrator, Doctor Jacques Hold, sees an elevating emptiness: "She seemed to expect nothing. She became a desert. A nomad. Homeless. She silently listens" (Duras, 1964, pp. 24-25). Lol's voyeurism reflects the social relations of a one-way mirror. God watches without being watched. Duras' aesthetic of ubiquitous spying echoes her experience under Nazi occupation. It similarly echoes the Vietnamese plight of 1931, with thousands of ICP members incarcerated following the Nghe An peasant insurrection, when seventeen year old Duras left Vietnam for France for the first time.

A Mirror Principle links Cycle to Ahmed Ali's (1910-1994) Twilight in Delhi (1940) through 'emptiness'. Elites confront a future which has ceased to exist. In Cycle, the European colonial elite in 1930s British India revel on the eve of imperial collapse. Twilight traces the surviving vestiges of a Delhi Muslim feudal elite, from the 1911 Coronation to the outbreak of World War I. Their cultural existence fades in the bloody aftermath of the 1857 Uprising and the destruction of the Mughal Empire. The Mughal dynasty have become beggars:

A beggar emerged from a by-lane, lifting himself up on his hands and dragging his legs along the floor ... There was a look of nobility on his bearded face, and his features unmistakably proclaimed that he was a descendent of Changez. ... Time has upturned the glass (Ali, 2010, pp. 149-150)

Every ruling elite in world history, seeking its own image, eventually encounters only a mirror of nothingness. "Nothingness" is the first Mirror Principle. Ali juxtaposes the post-1857 decline of the Mughal lifeworld with a premonition of imminent Raj collapse. His text thus accompanies Duras'. The "eventful year" of the 1911 Coronation marked "the height of British splendour in India", but from then "its downfall began" 
(Ali, 2010, p. 44). Twilight recounts: "night came striding fast, bringing silence in its train, and covered up the empires of the world in its blanket of darkness and gloom" (Ali, 2010, p. 275). This echoes Karl Marx: "entire sections of the ruling classes are, by the advance of industry, precipitated into the proletariat, or are at least threatened in their conditions of existence" (Marx, 2009, p. 33). "Night" implies natural forces beyond the structural transformations marking regimes of capitalism. This 'extinction' theme similarly pervades Cycle. Images of destructive ocean tides, dating from The Sea Wall (1950), reoccur menacingly.

Nothingness corresponds to irreversible World War II destruction. Twilight was deemed subversive by Empire. Ali recalls:

I received a letter from the Publishers one morning ... regretting that the printers found some portions of the book 'subversive' ... [These included] historical portions dealing with the War of Independence of 1857 ... [The] prospects of publication became as bleak as the wartime blackout ... most of its stock was destroyed in the Blitz...(Ali, 2010, pp. xvii-xviii).

This literary bombshell was among the first English language novels by an Indian Muslim. Twilight anticipates Cycle: the presence/absence dialectic, hidden linkages, polyphonic deconstruction of narrative omniscience, and socially transmitted memory in crisis. The patriarch Mir Nihal, while mourning the death of his secret concubine Babban Jaan from typhoid, provides the rule of interpretation:

This world is a house of many mirrors. Wherever you turn, you see your own images in the glass. They multiply and become innumerable until you begin to feel frightened of your own self (Ali, 2010, p. 118).

The second Mirror Principle is identity. The "world-house" suggests universal identity in existential dislocation. Similarly, in Lol, Jacques Hold invokes a "mirror of nothingness" to describe the triangle uniting himself, Lol, and Tatiana. Lol lies in a rye field observing them through a hotel window in the throes of love making:

The three of us must have been there already for over one hour, as she watched us coming and going within the frame of the window, this mirror of nothingness before which she sumptuously felt her desired exile (Duras, 1964, p. 124).

Lucy Stone Mcneece's Art and Politics in Duras' India Cycle describes Cycle as analysing declining 1930s colonial structures (Mcneece, 1996). Sirkka Knuuttila 
identifies trauma as driving Cycle (Knuuttila, 2011). Neither saga nor series, Florence de Chalonge argues, Cycle spirals recurrently around 'emptiness' (Chalonge, 2005). Rodolphe Kobuszewski sees Durasian themes (violence, pain and madness) indicating not pessimism but happiness in the 'non-self' (Kobuszewski, 2004). 'Emptiness' and 'non-self' equally characterize Twilight. The Mirror Principle undoes selfhood boundaries. Mir Nihal would protect family "purity". Losing control over family affairs with age, and facing imminent death, he becomes indifferent:

It mattered little whether Asghar married a low-born or a girl with blue blood in her veins. He would not be in [the world] anyway. He had lived his life, good or bad, done all he could for the children and the purity of his stock. Now it was their lookout whether they flourished or decayed (Ali, 2010, p.119).

Breaking caste laws, modernism is change and transgression. Aligarh Muslim University (founded 1920) wants to "make atheists of us all", he tells his sons (Ali, 2010, p.50). The Mirror Principle deconstructs "purity" in a Buddhist view of non-identity: "There is no term in Buddhist terminology wider than dhamma ... 'All dhammas are without Self”' (Rahula, p. 58). It is equally a Marxist view, where, upon removing all social relations, nothing remains: "All that is solid melts into air" (Marx, 2009, p. 25). The French Resistance meets post-1920 Indian nationalism in dialectical thought. Both Ali and Duras struggled with the $20^{\text {th }}$ century Left. Ali's 1932 Angaaray Collective included Communist Party activists. Yet Ali left the Left-oriented All-India Progressive Writers' Association (founded 1935) because of "differences over the meaning of 'progressive"' (Ali, 2018, p. Xxxiii):

[...] a rift started [over] a disagreement on the function of art and the artist in society. [Ali], unwilling to define the word progressive as 'communist,' 'proletarian,' or 'socialist realist,' went his own way. But he viewed the term as a mean trying for the betterment of our social life (Kumar, p. 57).

Duras similarly mistrusted the top-down Resistance-era Parti Communiste Français (PCF):

For her, little distinguished Stalinian and Nazi power, while loving the fraternity provided by the PCF. Yet she chafed against doctrinal conformism ... Duras believed literature a sacred space that ideology should not penetrate (Vircondelet, p. 54). 
The texts concern breaking free from cycles of abuse triggered by trauma. "Repetition" is the Kierkegaardian opposite to "dialectical" resolution. A Marxist vision of the triangular relations of exploitation, alienation, and exchange combines with an ontological concern with repetition and transgression for the stability of the social self.

The third Mirror Principle is empathy. Cycle depicts children undermining established racial dividing practices that protect colonial order (Duras, 1966, p. 56). Characters in Twilight discover and lose themselves in others. Empathetic flashes are socially revolutionary. To Mir Nihal, "it seemed that it was not the child but he himself who was crying" (Ali, 2010, p. 118). Asghar and Hameed love lower caste girls, pursuing self-destruction of caste identity against family and community wishes. A goat becomes a displaced object of sexual desire ("she would begin to caress the goat, then she would throw a glance at him"), collapsing human-animal identity boundaries. The fourth Mirror Principle is Memory. Memory triggers Asghar's association of an attractive "Chamar" girl (i.e. "Untouchable") with his childhood house in a cemetery, where his mother went insane, suggesting erotism conditioned by forgotten trauma (Ali, 2010, pp. 52-53).

The mirror moments - nothingness, identity, empathy and memory - trigger disorder. Asghar's mother urges: "Not so much should one go beyond his limit" (Ali, 2010, p. 56). There is a cultural Mirror Principle: the snake reflects ruptured social norms, of a son to secure the family name, of arranged child marriages, of obsessive caste boundaries ("We and they can't mix well") (Ali, 2010, pp. 57-59). No snake appears in the Qur'anic Eden. The Pharaoh's snake hallucination is eaten by Moses' staff become a real snake (Amir-Moezzi, p. 509). The snake in Twilight likely mirrors the Hindu snake-rope conundrum: "Something like a black rope creeps behind a wooden pigeon box. 'It's a snake. Bring my stick, Dilchain..." (Ali, 2010, p. 11). The Advaita analogy explains turiyam (absolute reality) and viswa (worldly experience), attesting to Buddhist influence:

The first non-Buddhist occurrence of the [snake-rope] analogy is present in Gaudapāda's Māndūkyakārikā ... This fact supports the hypothesis of Buddhist influence on the Advaita school. ... the analogy gained widespread popularity in Hindu philosophical texts as an expression of the misperceived metaphysical reality (Aklan, p. 20). 
Just as in the Mahabharata, the "snake is struck with a stick" to suppress uncontrolled lust and to punish the rapist (The Mahabharata, p. 266). The servant Dilchain was the likely victim (Ali, 2010, p. 45). This perhaps explains Dilchain appearing intoxicated, mad, crossing boundaries, laughing, and crying, i.e. traumatized, when beyond her master's sight (Ali, 2010, p. 157).

Ali's publications sought "reform":

[...] it made us famous overnight, the government banned the book as subversive, and our names were listed in the Intelligence Bureau as communists ... The mirror had warped our own image in reverse. The social order we had set out to reform, pronounced us West-Stricken devils! (Ali, 2010, p. 14).

Ali's term "West-stricken" reveals disdain for allegations of cultural inauthenticity. He upheld Indian "composite culture". Dilchain is a Hindu convert to Islam (Ali, 2010, p. 266). Twilight recurrently invokes "composite culture": "Though Islam permitted [Begam Waheed] to marry again, the social code, derived mostly from prevailing Hindu practice, did not favour a second marriage" (Ali, 2010, p. 36). Duras, too, celebrates "composite culture" through the Beggar of Bengal. A pregnant teenager, exiled from community, she walks several thousand miles from Cambodia to Calcutta seeking work, embodying India's internal mass labour migration. Driven by survival pressures, a multi-cultural universe of rich languages and customs simultaneously partakes of and is excluded from Indian national belonging. The Beggar must sell her baby before it starves or is eaten: "I would run away and leave her here to sleep ... but the dogs will come at the end of the market" (Duras, 1966, pp. 52-53). Her story mirrors the grinding poverty of those selling themselves at any price, or global capitalism. The Mirror Principle reflects the geography of power.

From stolen lilacs in a French garden to the padlocked grating of an impeccably ordered Calcutta enclosure, inclusion and exclusion express capitalist power. ViceConsul describes a "small house in Paris considered a mansion, surrounded by a garden, [which] has been closed up for years on end because its owner is in the consulate, this time in India: the police know who to warn in case of a fire" (Duras, 1966, pp. 33-34). The image of fire suggests the anger of the excluded. The iconic Beggar selling her baby in the open market suggests India forced to yield its future: 
This beautiful child is free to anybody who wants her ... look at my foot and you will understand why' ... inside, worms turn unceasingly ... She has no idea how much her foot stinks (Duras, 1966, p. 54).

The visceral depiction affirms Marx's account: "the worker sinks to the level of a commodity, and moreover the most wretched commodity of all" (Marx, 1984, p. 322). Land and labour reduce nature and human beings to commodities. The Beggar reflects a backdrop of manmade famines, a chain of crises created and exacerbated by colonial policy and culminating in the 1943 Bengal famine (estimated 2.1-3 million dead). The body horror scenes contrast with French colonial elites residing within a bubble, disturbed less by famine than by one colleague (the Vice-Consul) losing self-control and revealing the violent undercurrents puncturing their perfect world: "we are far more disoriented by the Vice-Consul than by the famine that is currently taking its toll on the Malabar coast" (Duras, 1966, p 157). The European compound is encircled by "metal fencing against sharks", and "metal fencing against beggars". One newly arrived colonial official naively ventures "outside" (Duras, 1966, pp. 101-102). Terrorized, he shows the stomach to rule has gone. In their ghost world, time is running out.

Twilight depicts Delhi where "the minarets point to heaven, indicating, as it were, that God is all-high and one." This hesitant monotheism introduces a multi-cultural city "built after the great battle of Mahabharat", mixing Hindu and Muslim kings, where "[d]estruction is in its foundations". Delhi has "now been ruined by the hand of Time" (Ali, 2010, pp. 4-5). This all-destructive force (i.e. "night") reoccurs: "What is the shadow hidden in the light which accompanies Anne Marie Stretter wherever she appears?" (Duras, 1966, p. 109). The shadow metaphor indicates an expiring social formation. A feudal patriarch adapts to capitalist conditions:

[Mir Nihal] flew his pigeons in the morning, then went out to work. He had a share in a shop of lace dealers. He had some property, no doubt, a bit of land in a village nearby and some houses in Delhi; but his growing family ... had necessitated some kind of business to increase his income. He was an aristocrat in his habits, no doubt, a typical feudal gentleman (Ali, 2010, p. 38).

Despite hating Empire, Mir Nihal's sons - upon whom he depends - extract wealth from it. Hence, "the shadows deepened and gradually the darkness increased around them." A family of collaborators, his youngest son, Asghar, rejects government 
service, preferring the upward mobility of business (Ali, 2010, p. 185). The recurrent dried husk of a dead date palm tree (a Qur'anic image) symbolizes hopelessness. The sons bear their father's name while betraying his 'outmoded' principles, suggesting his extinction. The natural environment declines simultaneously:

The sun was setting and the western horizon was dyed a dirty red for the atmosphere was not clear and the dust and the smoke of engines far away had made the air dirty and black. Flocks of pigeons rose from the house tops and were lost in the toneless colours of the darkening sky (Ali, 2010, p. 30).

The sons like English shoes and furniture. Certain traditional customs persist: "The girls were never consented about their own marriages". The birth of a girl means disappointment (Ali, 2010, p. 187,190). Even so, traditional Islamic customs are marginalized by imposed celebrations of Empire:

[Mir Nihal's son Asghar's marriage] had originally been fixed for the month of Eed, but had to be postponed till December as Mir Nihal's elder sons could not get long leave. They were busy making preparations for the coronation of George $\mathrm{V}$, which was to take place in December, and they had to send things and men for the event from their various districts to Delhi (Ali, 2010, p. 128).

Fatima Mernissi wrote: "The most horrible colonization is that which instils itself in your time, for there the wounds are to your dignity, and the resulting confusion borders on the pathological" (Mernissi, p. 141). Sugata Bose sees the "enigma of feeling in time [as] neither sufficiently theorized nor historicized" (Bose, p. 132). These texts suggest Wittgensteinian time: "if everything that we call 'being' and 'non-being' consists in the existence and non-existence of connections between elements, it makes no sense to speak of an element's being (non-being)" (Wittgenstein, p. 21).

\section{The Critical Literature: Mirror Principle as Repetition}

Alex Padamsee innovatively locates Twilight "within an evolving Urdu literary modernity since the late nineteenth century" (Padamsee, p. 30). His analysis identifies a mirror principle manifested in repetition:

If there is a victor here ... it is not so much modernity as the very principle of repetition, [amounting] to a narrative aesthetic ... By literally turning the plot into a 'house of many mirrors', estranging one experience in the reflection of another, Ali not only subverts the teleology of originality and decline, he 
questions the notion of a communal self that can be fully known to itself (Padamsee, p. 38).

Padamsee identifies parallels between characters who, superficially, might be antithetical. He questions the:

opposition between the originally coherent and static traditional model of Mir Nihal and the insistent and increasing Englishness of his son, Asghar. Mir Nihal himself represents the aspect of change he so deplores in his son. Ali chooses clothing to first delineate parallels rather than oppositions between them, illustrating the importance it had for conscious communal self-fashioning in the wider nation in the early twentieth century (Padamsee, p. 37).

Identity comes from a fashion industry. Difference conceals a hidden material unity. Mir Nihal wears an "embroidered round cap" at "rakish angle"; Asghar wears the "red Turkish cap cocked at a smart angle" (of the Caliphate movement) (Ali, 2010, pp. 9,12). These existential modes (nature or nurture?) constitute "repetition". Power abuse occurs in generational repetitions:

The story that follows of Asghar's courtship and marriage presents striking parallels with that of his parents. Where Mir Nihal's neglect and abandonment had made Asghar's mother mentally ill, we witness Asghar's wife Bilqeece succumb to a mentally debilitating condition brought on by the same treatment by her husband (Padamsee, p. 37).

Despite repetition, paradoxically, nothing returns to an original order. Chalonge has summarized Cycle similarly: "the anticipated closure or happy ending, as the return to an initial order, does not occur in Ravissement" (Chalonge, p. 241). No dialectical resolution produces comfortable closure. Lol's rupture with her fiancée, and subsequent mental breakdown, produces no new couple with Jacques Hold (as he conventionally desires). The structure is circular, but Lol is whirlpool rather than resolution: a "Night", a "black emptiness", or "never ending space" (Duras, 1964, pp 112-116). Her voyeurism undermines a delicately balanced hospital power system. The head doctor's wife, Tatiana, has required the junior doctor Hold to keep their perfect marriage (and the hospital) functional. It is the "absence" in Lol which "interests Jacques Hold" (Duras, 1964, pp.155-156), like the impulse to jump from a ledge. 
Chalonge observes that Lol and the Beggar remain haunted by memory (each for ten years) but without making whole what was broken. Their madness distantly mirrors the other. The exhaustion of wandering results in the Beggar's hallucination:

She had already waited at the end of markets. Today, she saw what she had waited to see: her parents' arrival at the base of the square. Unable to withstand their gaze, she respectfully prostrates herself. Upon rising from the ground, she sees her mother, at the opposite end of the market, smiling at her ... The Beggar falls asleep. When she awakens, a dazzling light fills the empty square where the market has vanished. (Duras, 1966, p. 27)

The Beggar never returns: "I will escape from my habit of following the waterline", she says. She becomes "irreversibly lost", resolving to go "where God passes for something better" (Duras, 1966, pp. 12,16). This rejection of accumulated value, or 'emptiness', mirrors Lol's identical obsession. Lol is a "hurricane of the night", "driving all habit from their lives" (Duras, 1964, p. 135). At the "Plain of Birds", transposed to the colonial settlement where her baby is finally exchanged for a coin, the Beggar abandons security for the open road:

The young girl has reached the Plain of Birds ... She will also abandon the Plain of Birds ... Her periodic pauses assure her survival, with men, on the edges of villages... (Duras, 1966, p. 59).

Duras was an anarchist. Why change things into something else? Emancipation is unbridled becoming. Padamsee's analysis of Twilight - that it "subverts the teleology of originality and decline, [while questioning] the notion of a communal self that can be fully known to itself" - applies equally to Cycle. No ending meets a beginning in harmony, as in Hegel's Phenomenology of the Spirit. How is pure irreversibility political? Overcoming "modernity" through "repetition" as an "aesthetic" recalls Antonin Artaud's anarchic "plague". Its proliferation disintegrates normal order, its multiplying selves transcend reason (Artaud, pp. 15-16). Heideggerian "repetition" indicates more "authentic" temporality than "objective" history, a "reverence for the sole authority that a free existence can have" (Heidegger, pp. 353,357). Both anarchist and reactionary embrace Nietzschean anti-epistemology.

Defending Islamism, Talal Asad theorized "complex space": the "tradition-rooted practice required to complete and perfect [oneself]" is incommensurable with modern 
"homogenous time" (i.e. secularism) (Asad, p. 179). Padamsee similarly sees Ali's "time as a matter of multiple transitions or 'passing", as "[challenging] the linearity of an Enlightenment narrative of modernity" (Padamsee, p. 35). These 'repetition' variants derive from Nietzschean "Eternal Return", a "world affirming" perspective "[wanting] to have what was and is repeated into all eternity" (Nietzsche, 1989, p. 68). Eternal Return bolsters existing injustice: "life itself is essentially appropriation, injury, overpowering of what is alien and weaker ... at least, at its mildest, exploitation" (p.203). It sees "dialectics is a case of decadence". Against "equal rights", Nietzscheanism sees not "consequences", but "an instinct for cleanliness" (Nietzsche, 1992, pp. 9, 82, 14-18). Marxian universalism, by contrast, emphasises contradictions and consequences. In Marx's concern for the millions who earn little, and remain one illness away from losing their homes, their families, and their lives, epistemology underpins a practice for reordering the world. In Cycle and Twilight, is the Mirror Principle a rejection of epistemology?

\section{The Enlightenment Horizon: Mirror Principle as Activism}

This is unlikely. True, Duras and Ali rejected socialist realism, therefore rejecting "fixing time within a single trajectory" (Padamsee, p. 35). Twilight and Cycle, however, partake of the oneiric socialism of Mac Orlan's 1927 Le Quai des Brumes (Port of Shadows). Michel Kraus is a "police painter" who sees "things hidden behind things". He says, "I would see a crime in a rose" (Orlan, p. 40). Exchange value, a universal identity in global capitalism, is tainted by hidden violence. As technology changes, exchange modes change, while the predatory logic of capitalism persists.

Ali embraced equality, revealing convictions about "linear" (i.e. "dialectical") historical change. His 1932 publication of Angaaray ('burning coals' in Urdu), with a collective, was called "piety destroying" by orthodox north Indian Muslims (Ali, 2018, p. vii). Fatwas incited execution, while gynaecologist Rashid Jahan (the only woman) was threatened with an acid attack. Angaaray was banned in 1933, citing protection of the "religious feeling of any class of His Majesty's subjects" (Ali, 2018, p. ix). Ali's “The Clouds Aren't Coming" critiqued gender oppression:

Don't tell me that God is a collection of merciful actions ... what kind of wretched existence is life as a woman: worse than being a tick. She works, she labours, sewing clothes, cooking meals, from morning till night ... she has the privilege of producing children. Whether she wants to or not, when her husband wants to, he 
just grabs her by the hand and drags her ... May he die an early death ... Why are we powerless? If we had our own money, we wouldn't have to endure this humiliation. We could do whatever we wanted whenever we wanted (Ali, 2018, pp. 81-83).

This "dialectically" identifies structures of gender oppression, then projects their negation through power redistribution. Ali recalls:

A few of us, filled with dreams of freedom and independence, made bold to publish in 1932 a collection of our short stories ... to show a mirror to society (Ali, 2010, p. XIV).

The Mirror Principle was, then, a device for social reconstruction. Nothingness, identity, empathy, memory, and geography were incidental to this teleological purpose. Teleology is epistemological: we have to move forward to learn cause-consequence lessons. Legally instituted gender equality overcomes the "repetition" of tradition. The Angaaray manifesto described the:

duty of Indian writers [as assisting] the spirit of progress in the country by introducing scientific rationalism in literature ... [It must deal with] ... problems of poverty, social backwardness and political subjugation. All that arouses in us the critical spirit, which examines customs and institutions in the light of reason, which helps us to act, to organize ourselves, to transform, we accept as progressive (Ali, 2018, pp. X-xi).

Progressive temporality is not "repetition". Ali questions the very concept (rather than the existence) of God: "What bad fortune to have been born into a Muslim family. Let this religion burn! ... Comfort for the soul? It's only a comfort for men. What good is it to a woman?" (Ali, 2018, p. 84). However shocking, Ali was no atheist. In 1988, his esteemed if controversial Al-Qur'an. A Contemporary Translation was a landmark (Robinson, p. 73). Ali saw God mediated through power relations. Angaaray progressively broached marital rape, birth control, education, and women's right to work, following the radical Enlightenment tradition of building new egalitarian social orders. In Cycle and Twilight, women's bodies perpetuate property and the male line in bourgeois 1930s France and the Raj.

The Mirror Principle critiques violence. Anne Marie Stretter is the Vice-Consul's double. The Vice-Consul shoots a revolver randomly "at night upon the Gardens of 
Shalimar where lepers and dogs had taken refuge". This murder is a mirror moment. Someone notes: "bullets were also found in the mirror inside his residence" (Duras, 1966, p. 95). Killing others was killing himself. If Stretter represents "perfection" concealing ugly colonial realities, the Vice-Consul exposes those realities. Stretter therefore urges that unless the Vice-Consul is "forgotten", it is "impossible to recognize her" (Duras, 1966, pp. 137-138). This reflects an ethical interrogation. Someone asks: "Is this really killing to kill lepers or dogs?" (Duras, 1966, p. 95).

These texts therefore transcend a "narrative aesthetic" (Padamsee) or "repetitive character" (Chalonge, p. 252). An ethical question in the Utilitarian tradition addresses the limits of a circle of moral consideration in self-other relations. Power unconsciously constructs conventional limits through 'repetition'. When is killing right or wrong? How to decide who falls inside or outside of a shifting - and historically arbitrary conceptual boundary? This is neither the Hegelian "absolute" nor Engels' Dialectical Materialism (i.e. "a single trajectory"). Existing Soviet socialism ignored the communicative principle, citing "inevitability". Authoritarian epistemology corresponded to political violence: 1930s show trials and purges, enforced collectivization and labour camps. Duras and Ali shared the Enlightenment outlook of Gaston Bachelard, of "keeping the dialectic open" (Bachelard, p. 24).

Twilight and Cycle depict women as oppressed worldwide. An unspoken act of male violence likely resulted in the tragic pregnancy that shattered the family in Twilight. The brother and sister recall their childhood, isolated in a deserted house with their mentally ill mother, surrounded by graves, while carefully refraining from uttering the memory:

'Mother had lost her reason ... she would tear her clothes and wander about the house ... 'You were too small to remember it. Mother's illness started when Dilchain [the servant] had a son who died later...' 'Oh, yes I have heard that father and Dilchain....' Asghar put in, but Begam Waheed quickly hushed him into silence... (Ali, 2010, p. 47)

Twilight shows women buried alive through the Zenana system:

Walls stood surrounding them on all sides, shutting the women in from the prying eyes of men, guarding their beauty and virtue with the millions of their bricks ... The day dawned, the evening came, and life passed them by (Ali, 2010, p. 39). 
'Repetitions' refer to the traumas that triggered them. They provoke the quest for what Sugata Bose has called "a different universalism", rejecting Eurocentric universalism tainted by imperialism. Involving "human agency, imagination and action", a rational quest involves changing people's views (Bose, pp. 233, 268, 4). Duras' first 1940 publication supported Empire (Vircondelet, p. 38). Family milieu, upbringing, and traumatic abandonment by her mother provide explanations. Why Duras then renounced childhood indoctrination, embracing universal humanism under Nazi occupation, requires deeper reflection. Having constructed Anne Marie Stretter from an idolized childhood colonialist, Duras deconstructively juxtaposed her with the Vice-Consul. Duras thereby opened the empathetic horizon for the Beggar, embodying the wretched of the earth.

\section{Trauma and Roots: Imagining the Human Condition}

Paul Ricoeur's Memory, History and Forgetting (2000) analyses how objectively documented official history intersects with human memory. Both, he argues, are partial creations of a deeper public forgetting which fashions 'official' history. The three constructs are triangular. The existential trauma centring Twilight is empirical 'history', in the organized obliteration of the Mughal Empire, and replacement of the East India Company with the Raj State in 1857-8.

The 1857 Uprising saw three hundred mounted Meerut sepoys entering Delhi and forcing the imprisoned Emperor Zafar (1775-1862) to leadership. An unpaid peasant army fought the British army, which, with Sikh and Pathan levees, sacked the capital. A nineteen-year-old British officer recalled "orders to shoot every soul". Food prices inflicted starvation. Zafar was displayed "like a beast in a cage", silently writing poetry on the wall with a burned stick (Dalrymple, pp. 1-8). The "Muslim conspiracy" rumour, meanwhile, triggered the North Indian campaign of extra-judicial killings and dispossession. Muslims, expelled from Delhi, were required to pay 25 per cent of the value of their property prior to return (Padamsee, p. 32). A traumatic memory, literary critic Closepet Dasappa Narasimhaiah explains that "first-hand knowledge of the depths of degradation of a whole people" was a cornerstone of English language literary production in colonial India (Narasimhaiah, p. 4).

Ricoeur's 'memory' is less straightforward. Twilight broaches the lost Indian roots inflicted by the 1857 trauma. Ainslie Embree's 1958 Sources of Indian Tradition showed how, for every element of Indian tradition, multiple and conflicting currents 
exist. Understanding Ali's lost roots requires hermeneutical reconstruction of "sources", revealing the charged politics of memory. A clash between 'official history' and memory plagues Ali's family recollections:

My grandmother was five and my grandfather eleven when the ghadar of 1857, the blind persecution and massacre of the citizens of Delhi, took place. The triumphant British held an orgy of blood and terror, all mention of which has been dropped by their historians (Ali, 2010, p. xiv).

Ali invokes a global trauma of violent uprooting, repetitions implying abstract fraternity among colonized populations beyond Delhi Muslims:

wandering from jungle to jungle, village to village, in search of food and shelter, they trudged back from exile ... they had to restart life as paupers and vanquished people, like the Aztecs and Incas of Mexico and Peru three hundred years before them... (Ali, 2010, p. xv)

Ali voices a larger principle in calling for "India free of the Fascist Jan Sangh movement which is blotting out the image of the real and traditional India" (Ali, 1968, p. 19). Indian ethnic and civic nationalisms followed the 1857 carnage. Ali conflicted with Indian contemporaries who rejected a multi-cultural "composite India" to 'retrieve' a 'pure' Hinduism or Islam, or revivalist 'repetition'.

Ali's mirror was the world. He embraced transnational communication, presupposing empathy and reason, using multiple languages in a cosmopolitan spirit, promoting translation as solidarity:

In 1949, Ali published The Flaming Earth: Poems from Indonesia (1949), possibly the first anthology of modern Indonesian poetry in English translation, and Muslim China (1949), a study of China's Muslim populations, an outgrowth of his interest in China [and mastery of Mandarin] (Kumar, p. 57).

Ali's English writing was political:

This cause [of Indian independence] deserved a worldwide audience. If presented in Urdu, it would lie down within a narrow belt rimmed by Northwest India ... (Ali, 2010, p. xvi).

Ali used Aldous Huxley's concept of the "Isness" (1954 Doors of Perception) in a 1968 article defending Indian "composite culture". Celebrating novelist Raja Rao, Ali 
described "two lads of sixteen [who] met for the first time. One was a Muslim and a student of Aligarh, the other was a Brahmin from Mysore" (Ali, 1968, p. 16). Twilight depicted Delhi Muslim identity metamorphosing through distant events like the 191516 Battle of Gallipoli (Ali, 2010, p. 175). The call to "drive them out of the country" did not correspond to a closed society (Ali, 2010, p. 241, 148).

Cycle reflected Duras' traumatic Occupation days. Embree's insights on Indian pluralism apply equally to other societies. Duras' own account declares her "birth [as a writer occurring] with the revelation of Auschwitz" (Vircondelet, p. 48). Duras joined the PCF to save her husband, Robert Antelme, a Dachau prisoner. In the Resistance, Duras used the lure of seduction to entrap the Gestapo agent who had arrested her husband (Duras, 1985, pp. 91-135). Upon returning from Dachau, Antelme wrote L'espèce Humaine, questioning a possible universal humanity following the Holocaust. Duras' Cycle, as explained in La Douleur, followed this endeavour.

The PCF was the major organized force driving the French Resistance (Arnaud, p. 147). Its secular and republican principles dated from the 1848 revolution, fusing political and social revolution. Between the 1873 National Assembly re-embrace of theocratic, monarchic, and authoritarian politics, under Colonel de Broglie's "Moral Order", and the 1894 Dreyfus Affair onset, a French proto-Fascism emerged around the invented facts in Edouard Drumont's 1888 anti-Semitic La France Juive (Duclert, p. 241). This tradition foreshadowed the Vichy collaboration.

In 1945, a skeletal Antelme returned to France from the forbidden section of Dachau for "the dead and hopeless cases". Larger principles defined Duras' personal tragedy. Antelme's refusal to blame his tormenters upon ethnic grounds moved Duras. She notes: "Robert accused no one. No race. No people. He accused humankind. ... He accused no one except the governments which are a fleeting presence in the history of peoples" (Duras, 1985, pp. 65-67). This contrasted with Duras' intimate feelings: “I could have hated them ... to the point of massacring them all, until the entire German population was wiped from the earth. Today, however, between hating them, and loving [Antelme], I can barely distinguish the two emotions". Trauma is this thin line:

I screamed out that no, I did not want to see him. I headed away, climbing the staircase. ... The war shot out of me in screams. Six years without screaming (Duras, 1985, p. 38). 
During Duras' subsequent alcoholism, she meditated upon God:

[Alcohol] is reason seeking understanding to the point of madness ... why this Reign of Injustice ... We lack God. This emptiness discovered in adolescence remains permanently. Alcohol was invented to withstand the emptiness of the universe, the rocking of the planets, their imperturbable rotation in space, their silent indifference to our pain (Duras, 1987, p. 25).

In a sanitorium, Duras undertook Ravissement suffering delirium tremens, seeking to dispel illusions of 'real' identity (Vircondelet, p. 22). Lol overcomes God. God is "dazzled and wearied by the sight of [her as] a naked woman". Ultimately, after "long waiting in vain", "one day a weak body stirs in the belly of God" (Duras, 1964, pp. 5051). Lol impregnates God with 'emptiness". Recurrently, we hear that "Lol is not God, she is no one" (Duras, 1964, pp. 47, 49). Lol destroys what Jorge Louis Borges called "the Library of Babel", the "power of the Word" (Borges, pp. 78-87). Lol is "silent", experiencing a "word-absence, a word-hole, a deep hole where all of the other words had been buried" (Duras, 1964, pp. 47-48).

Lol's martyr's smile echoes Antelme:

I do not recognize him. He looks at me. He smiles ... A supernatural exhaustion shows in his smile, from having managed to survive until this moment (Duras, 1985, p. 69).

The Beggar's visceral hunger also echoes Antelme:

[T]here have already been accidents here in Paris from letting concentration camp survivors start eating solids too quickly ... If he had eaten upon his return from the camp, his stomach would have ripped open under the weight of the food. ... No, he could not eat without dying. And he could not remain any longer without eating without dying (Duras, 1985, pp. 70-71).

Durasian "emptiness" is invoked as a "memory in tatters":

He has disappeared, hunger has taken his place. The emptiness has taken his place. He is giving to the pit, he fills what was empty... (Duras, 1985, p. 77).

Like Ali, Duras condemned the 'oblivion' (in Ricoeur's sense) perpetrated by official discourses. Charles de Gaulle, discussing the 1870 Sedan defeat, silently passed over the Paris Commune: 
De Gaulle does not speak of the Commune ... for De Gaulle, [it] is a consecration of the perverted propensity of peoples to believe in their own existence and their own strength (Duras, 1985, p. 45).

Duras' vision of the French revolutionary future was identified with the aims of the 1871 Paris Commune. Emptiness is hunger, not a metaphysical abstraction. Duras described herself as from "nowhere" and a "foreigner" (Vircondelet, p. 38). Duras and Ali pursued socially egalitarian commitments while rejecting Soviet dogma and repressive practices. Both were obsessed with a non-traditional idea of "God". The "human condition" was predicated upon 'emptiness', a variant of Ricoeur's 'oblivion'. The Mirror Principle combined socialist revolutionary commitment with religious fervour.

\section{Revolutionizing the Proustian tradition: nothingness and emptiness}

Duras and Ali break from Mac Orlan in centring memory. The Beggar hallucinates her mother: "It is not yet madness. It is hunger, hidden by a resurgence of fear, the asthenia of seeing the lard and smelling the soups. It is her mother's love expressing itself by chance ...” (Duras, 1966, p. 27). The Proustian past rematerializes through random material triggers. Both Duras and Ali read Marcel Proust. Duras sought childhood memories from Vietnam. For Ali, not Mughal politics but the old Delhi lifeworld mattered: "my purpose in writing [Twilight] was to depict a phase of our national life, ..., values now dead and gone" (Ali, 2010, p. xxi)..

Duras and Ali affirmed radical democratic elements within their own cultures, while spurning authoritarian elements. The Indian "composite" tradition and the French republican tradition meet, through them, in the Proustian imagination. On February 23, 1941, Ali wrote from Lucknow University to his London publisher:

I can, at least so long as I do not see it again, think of the old London, and of you and other dear friends walking its old streets, living and talking and meeting at parties in its warm and pleasant houses. Most of those restaurants and pubs we frequented must have all gone now. But for me they still exist as they did. (Ali, 1941).

Ali viewed the "damage done by colonial powers to the heritage of conquered peoples [as] irreversible". However, "memory is a collective storehouse that time and history cannot eradicate" (Ali, 2010, p. ix). Proust saw "the only real universe [as] that of 
art, and the only real paradise [as] lost" (Maurois, pp. 17-23). Proust's madeleine triggered retrieval of lost time. He distinguished voluntary from involuntary memory:

[...] my memories were provided uniquely by voluntary memory, the memory of intelligence, [and] the information it gives retains nothing of the past ... an entire reality remained dead for me. ... Dead forever? It is possible. There is a great deal of chance in these matters .. All efforts by our intelligence are useless. The past is hidden outside of its domain and its reach, inside of some unsuspected material object. This object depends upon the random possibility that we encounter it before we die (Proust, pp. 57-58).

Genuine past knowledge is without relation to intellect or will. It is a chance 'repetition'. Consciousness is minor in forming ourselves. Action follows not thoughts, but something unknown. The past, awaited like God, may never happen. Duras and Ali revolutionized the Proustian tradition. The hungry cannot wait.

Duras complained that "Marxism stops at inner life." Seeing life as a "search for God", she esteemed "the void over politics" (Vircondelet, p. 104). Duras' reflections on God correspond to, possibly, Simone Weil's (1909-1943) 1947 Pesanteur de la Grace. Weil, a 1933 French general strike organizer, Spanish Civil War republican, and French Resister, wrote:

Supernatural love touches only creatures while uniquely reaching God. It is only creatures which it loves (what else have we to love?), but it loves them as intermediaries. For this reason it loves all creatures equally, itself included. To love a stranger as oneself implies the reverse: to love oneself as a stranger (Weil, p. 43).

Weil's Mirror Principle of God borrows from Hindu-Buddhist non-attachment: "the real presence of God is in everything not veiled by imagination" (Weil, p. 45). The imagination implies desire and hence attachment. Universal identity is 'emptiness'. When the Beggar, expelled from community, must seek the mythic "plane of birds", it is a world "so distant that it becomes impossible to have even the slightest imagining of your surroundings" (Duras, 1966, p. 11).

Duras explained the opening trauma in Cycle, giving the key to its interpretation:

To write is not to tell stories ... It's telling everything at once ... It's to tell a story which occurs through its absence. Lol V. Stein is destroyed by the ball of S. Thala. She is created by the ball of S. Thala. ... at the moment of the ball, Lol is so swept 
away by the spectacle of her fiancée and this stranger in black, that she forgets to suffer. ... It is this suppressed pain that eventually drives her insane (Duras, 1987 , p. 35).

This presence/absence creation/destruction dialectic suggests the revisiting powers of the unconscious. The question remains: what gave Stretter so mesmerizing an aura? Lol becomes entranced by a sight which should appal her. The Vice-Consul explains Stretter's almost supernatural power over others. Edward Said identified an intersection of "power, scholarship and imagination", where "to reside in the Orient is to live a privileged life, not of an ordinary citizen, but of a representative European whose empire (French or British) contains the Orient in its military, economic, and above all, cultural arms" (Said, pp. 329, 156). For the whites in Vice-Consul, a fabulous life of open space, mobility and beautiful possibility exists connected merely to skin colour, birthplace, and a power construct providing identity. The Indian masses, meanwhile, starve in the textile mills. A dialectical or revolutionary obsession drives Duras' encounter with memory, in remembering events anew from the perspective of the most oppressed. This activism is alien to Proust.

The Beggar equates the "plane of birds" with escaping habits and attaining "emptiness" (Duras, 1966, p. 16). Stretter, meanwhile, embodies 'nothingness', invoking George Orwell's question in 1984: "Does the past exist concretely, in space? Is there somewhere or other a place, a world of solid objects, where the past is still happening?" (Orwell, p. 282). Stretter inspires "forgetting", making frightened men love her (Duras, 1966, pp. 104-106, 158-9). Memories of oppression become beautiful dreams of "enduring perfection" in a "smooth pink woman", occluding the unspoken reality of a growing Indian insurgency (Duras, 1966, pp. 46-47).

Two distinct concepts emerge, Dalit and Indian national leader Bhim Rao Ambedkar's Buddhist-inspired 'emptiness' and Edgar Allen Poe's 'nothingness'. Ambedkar's 'emptiness', opposing Untouchability, Empire, and Soviet orthodoxy, differs from the Western concept "nothingness" expressing remorse over an absent God associated with a justificatory Theodicy. In Poe's "materialism of decay", there is no "saving the mind from nothingness" (Poulet, p. 301). Jean Paul Sartre echoed this: "Nothingness lies coiled in the heart of being - like a worm" (Sartre, pp. 16-21). Nagarjuna, by contrast, sees not "intrinsic" but "relational" identity. Like Wittgenstein, 
cited earlier, "a phenomenon not antecedently existent comes to be" (Nagarjuna, pp. 138, 111). There is neither enduring identity nor being, in contrast with "the God of Eternity who pervading all sustains all" (Krishna's Dialogue on the Soul, p. 33). Ambedkar linked Buddhism and Marxism, seeing the world as multiple relations, in his 1936 "network" theory of society:

Nowhere is human society one single whole. It is always plural. In the world of action, the individual is one limit and society the other. Between them lie all sorts of associative arrangements of larger and lesser scope- families, friendships, cooperative associations, business combines, political parties, bands of thieves and robbers (Ambedkar, p. 278).

This approximates how Ali and Duras imagined 'emptiness' in the national constructions of the French Resistance to the Indian freedom struggle. The Buddhist traces in Durasian thought needn't surprise us. Duras acquired her 'Indian' worldview in childhood from mixing with Vietnamese children in a bilingual world, having been relegated to the 'native' level by wealthier white people because of family poverty (Vircondelet, 19).

\section{Nation and Teleology}

Padamsee critiques a "teleology of extinction" (Padamsee, p. 29). The argument relies excessively upon Partha Chatterjee's 1986 Nationalist Thought and the Colonial World. A Derivative Discourse. Indian nationalism is enslaved within the "ambit of bourgeois-rationalist thought", producing the "lack of autonomy of nationalist discourse itself". The "universal ideal" of the "Enlightenment" is the "implantation into new cultures of an alien framework" (Chatterjee, pp. 10-11, 27). It is the Evil Mirror argument.

Splicing Marx with Heideggerian anti-epistemology, Chatterjee targets the "bourgeois-rationalist conception of knowledge, established in the post-Enlightenment period of European intellectual history." It is "the moral and epistemic foundation for a supposedly universal framework of thought which perpetuates, in a real and not merely metaphorical sense, a colonial domination" (Chatterjee, p. 52). Following Being and Time, "the problem of knowledge is annihilated" because "being" has deeper importance (Heidegger, p. 57). Marx the sociologist, and Heidegger the hermeneutician, cannot cohabitate within one theoretical optic. One must die. Chatterjee makes his choice. Marx the sociologist dies. 
For Padamsee, "extinction [in Twilight] effectively becomes a means of passage". If no original self exists, then existential dissolution is a new becoming. This openendedness conceivably invokes Mohammed Arkoun's call for "the deconstruction of every form of orthodoxy falsely rendered sacred by historical figures who happened to succeed politically", citing "an abundance of meanings" that "may yet experience more historical growth" (Arkoun, p. 47). However, Heideggerianism reduces 1930s Indian nationalism to a "politics of communal grievance and political isolation". While certainly troubled, 1930s nationalism, in its pathbreaking complexity, is irreducible to a "normative and singular teleology of the nation" (Padamsee, p. 42, 29).

Mahatma Gandhi's 1930 Civil Disobedience Movement invoked "the starving millions, the sick, the maimed, and the utterly helpless". Sarojini Naidu became the first woman Congress President. The 1931 Karachi resolution introduced socialism into Indian nationalism, declaring that "to end the exploitation of the masses, political freedom must include real economic freedom of the starving millions" (Chandra, pp. 270-274, 284). Ambedkar's landmark 1936 Annihilation of Caste appeared. True, "communalist" parties surged especially after 1937: the paramilitary RSS (founded 1925) represented "Hindu nationhood", Punyabhu (Holy Land), claiming immutable religious roots (Sharma, 2007, p. 58). Its one-party politics, echoing European Fascism, turned Indian Muslims and Christians into "aliens" overnight. These multiple paths are irreducible to "nationalist tropes of temporal disjunction and extinction", or the $18^{\text {th }}$ century Enlightenment modernity/tradition dichotomy (Padamsee, p. 28).

Padamsee invokes "Heidegger's insight that being in time ... is a matter of 'passing' or travel" (Padamsee, p. 41). This mistakenly sees Heidegger giving genuine value to unreproducible moments. This characterized Nagarjuna, for whom perpetual "forgetting/ remembering" is intrinsically human (Vivenza, pp. 212-213). Politics cannot salvage it. For Heidegger, during the Nazi era, the "forgetting" of "being" required a revivalist state to restore public recollection. Such organicism is misleading for understanding Duras or Ali, neither of whom gave retrieval of "being" political priority.

\section{The Heideggerian nation}

Twilight juxtaposed with the spiritual father of Pakistan, Mohammad Iqbal, reveals Ali's national ideal. The 1930s Pakistan movement was minimal in 1921. Indian Muslims were diverse in language, caste, and ethnicity, lacking common political 
organization, or territory (Wolpert, p. 75). Empire backed Muslim communalists against multi-cultural Congress nationalism, manipulating false hopes through divide/rule strategies. Viceroy George Curzon promised East Bengal Muslims a "unity which they have not enjoyed since the days of the old Mussulman Viceroys and Kings" (Chandra, p. 125). The Pakistan dream materialized later, in Iqbal's vision of a loose North-West Indian configuration (Wolpert, p. 75).

Iqbal was indebted to German Orientalist Friedrich Hommel, his teacher in Munich. The Reconstruction of Religious Thought in Islam (1930) advanced Heideggerian anti-epistemology, with "modern man robbed of faith in his own future", as his "secret despair hides behind the screen of scientific terminology". Modern man, "absorbed in fact", is "cut off from the unplumbed depths of his own being". "Modern materialism" produces "despair and anxiety" (Iqbal, pp. 73-74). Scarcely traditional Islam, it anticipated Taliban graffiti on the Kabul Ministry for the Prevention of Vice and the Promotion of Virtue: "Throw reason to the dogs. It stinks of corruption" (Burke, p. 122). Hailing the "remarkable homogeneity" of the "culture of Islam", Iqbal reduced linguistic and cultural diversity to inauthenticity. Islamic authenticity, Iqbal argued, required removal of a "magian crust":

[...] a Magian crust has grown over Islam ... Indeed, my main purpose in these lectures has been to secure a vision of the spirit of Islam as emancipated from its Magian overlayings (Iqbal, pp. 60-63).

Heideggerian utopia is absent in Twilight. In a superstitious world of hybrid cultures, metaphorical animal attacks and musical intoxication, caste and gender govern conduct in complex relation to colonial power. Between new middle-class government service, grave robbery amongst the immiserated masses, and the deadly global 1919 epidemic, "a death in life" is sociological (Ali, 2010, p. 70). Youth pursue terrorist violence to overthrow an Empire which, for their parents, meant the extinction of a world the youth can never know.

\section{The nation as "composite culture"}

Ali promoted "composite culture". It has four defining moments:

(1) The Akbarian precedent: in the $16^{\text {th }}$ century Mughal state under the Emperor Akbar, a dialogical "public sphere" defined the composite nobility. The Ibkahat (House 
of Worship) became an open symposium for all religions - Sunnis, Shi'as, Hindus, Jains, Zoroastrians and Christians - to conduct dialogues non-violently. Akbar argued that with "reflection", people "shake off the prejudices of their education, the threads of the web of religious blindness break" (Abul-Fazl, p. 171). The Ibkahat was preceded by popular Hindu-Muslim unity in Bhakti and Sufi movements, united in yogic practices and tolerance. This was "a force of social energy greater than the state" (Mukhia, p. 33).

(2) The Sufi legacy: Amir Khusrau (1253-1325), a popular court poet, articulated India as a universal home: "If a Khurasani, Greek or Arab comes here/He will not face any problems/For they will treat him kindly, as their own" (Sharma, 2006, p. 88). His father had fled Central Asia following the Mongol invasions, arriving in India as a refugee (Rizvi, p. 168). Khusrau evoked the "pain of the mother" in children lost to war, called the slave the "child of a man", and beseeched Hindu-Muslim unity: a "needle is better than a (cutting) sword" because it "binds" (Khusrau, 2010).

(3) The Gandhian National Movement: The Gandhian strategy "did not require any particular political or ideological commitment from its activists", only "commitment to democratic and secular nationalism" (Chandra, p. 79). This permitted wide public inclusion, with "many more women in positions of importance than in the Russian and Chinese revolutionary movements put together" (Chandra, pp. 46-47). Gandhi said: "We were able to enlist as soldiers, millions of men, women and children, because we were pledged to non-violence" (Tendulkar, pp. 3, 78). The core was Hindu-Muslim unity. The Non-Cooperation Movement (1919-22) expanded beyond cities to workers, peasants and the villages, appealing to all religions and classes: "Muslim participation [gave] the movement its truly mass character"; "at some places two thirds of those arrested were Muslims" (Chandra, p. 196).

(4) The Tagorian literary revolution: Rabindranath Tagore's core insight was noncoercive "development". A Zamindar, Tagore had Muslim tenants whose daily religious boundary crossings fostered his conviction of Hindu-Muslim syncretism. Tagore said: "If we could free even one village from the shackles of ignorance and helplessness, an ideal for the whole of India would be established." Tagore rejected state-centred politics for grassroots institution-building (Bhattacharya, 2017, p. 7). His World War I novel, Home and the World (1916) confronted horror: Hindu-Muslim riots, demagogic and identitybased violence, terrorist strikes, and colonial violence. Tagore conceived cultural identity 
as "flowing currents", not a "fixed or stable object" (Sharma, 2007, p. 12). The complexities of modernization, Home and the World suggests, require sincerely listening, or empathically sharing incommensurable experience. Tagore urged that "freedom" be rooted in "small things" (Tagore, pp. 30, 202-203). Tagore emphasised storytelling as one need of masses in the modern world. No single voice suffices.

The spirit of Indian tradition is similarly evoked by Ali. Duras, whose identity was plural and messy, rebelled against the homogeneity of the French national tradition, aspiring to a similar multi-culturalism.

\section{Conclusion}

Divide/rule was Empire's legacy. Journalist M. J. Akbar described the tragic 1947 Partition:

trains coming from Pakistan full not of refugees but of corpses and scattered, barely stirring bodies of survivors ... trains going towards Pakistan had their own horror stories to tell.

Partition violence left 14 million people displaced in the largest population movements in recorded history. Over one million Sikhs, Hindus, and Muslims were killed in widespread organized violence (riots, massacres, rape) (Akbar, pp. 424-425, 415). Ali was Visiting Professor in Nanking. Indian authorities in 1948 refused his re-entry, calling it "a question of Hindu and Muslim"' (Ali, 2010, p. xix). Duras, at this time, saw her childhood experiences of colonialism "reflected" back in the horrors of Hiroshima and Auschwitz (Vircondelet, p. 24). Both used a Mirror Principle, much as Proust's roman onirique was an "allegory for the creation of the world" (Tadié, p. 114). It is a world of walls: "the walls increase in number, multiply, cut ... make the eyes bleed" (Duras, 1971, p. 110). Both recurrently depict walls and exclusions echoing Orwell's 1984:

everywhere, all over the world, hundreds of millions of people just like this, people ignorant of one another's existence, held apart by walls of hatred and lies (Orwell, p. 209).

The politics of 'emptiness' and the 'non-self', paradoxically, require protection of the person: "after the death of the moral person and annihilation of the juridical person, the destruction of the individual is nearly always crowned with success" (Arendt, p. 271). It requires, not as Kierkegaard thought, eternal habit linked to God, but the revolutionization of habit to eliminate systemic and avoidable suffering. 


\section{References}

Akbar, M.K. (2002). Nehru. The Making of India. Roli.

Aklan, Anna (2018). The Snake and Rope Analogy in Greek and Indian Philosophy. Annual of Medieval Studies at C.E.U., 24. Central European University.

Ali, Ahmed (2010). Twilight in Delhi. Rupa.

Ali, Ahmed; Mahmud-uz-Zafar, Jahan, Rashid, \& Zaheer, Sajjad. (2018). Angaaray. (Snehal Shingavi Trans.). Penguin.

Ali, Ahmed (1968). Illusion and Reality: The Art and Philosophy of Raja Rao. Journal of Commonwealth Literature. 3(1). 16-28. https:// doi.org/ 10.1177/002198947000500103

Ali, Ahmed (1941). Letter to John Lehmann, Hogarth Press. Retrieved from Modernist Archives Publishing Project.

https:// www .modernistarchives.com/ correspondence/ letter-from-ahmed-alito-john-lehmann-23021941

Ali Amir-Moezzi, Mohammad (2007). Dictionnaire du Coran. Robert Laffont.

Allami, Abul-Fazl (2008). The A-In-I Akbari. Volume I. Low Price Publications.

Ambedkar, Bhim Rao (2014). Annihilation of Caste. The Annotated Critical Edition. Navayana.

Arendt, Hannah (2002). Le système totalitaire. Seuil.

Arkoun, Mohammed (2002). The Unthought in Contemporary Islamic Thought. Saqi Books.

Arnaud, Jean-Charles, Geny, Emeline, Lamy, Goutier, Tillier, Alice (2019). Atlas de L'Histoire de France. Sens.

Artaud, Antonin (1993). The Theatre and its Double. Calder.

Bachelard, Gaston (2009). Le Nouvel Esprit Scientifique. P.U.F.

Bhattacharya, Sabyasachi. (2017). Rethinking Tagore on the Antinomies of Nationalism. In K. Tuteja, \& K. Chakraborty (Eds.), Tagore and Nationalism (pp. 17-30) Springer. https:// doi.org/ 10.1007/978-81-322-3696-2_2

Borges, Jorge Luis (1964). Labyrinths. London.

Bose, Sugata (2006). A Hundred Horizons. The Indian Ocean in the Age of Global Empire. Harvard University Press. https:/ / doi.org/ 10.4159/9780674028579

Burke, Jason (2004). Al-Qaeda. The True Story of Radical Islam. Penguin. https:// doi.org/ 10.2307/4147572

Chalonge, Florence de (2005). Espace et récit de fiction. Le cycle indien de Marguerite Duras. Presses Universitaires du Septentrion. 
Chandra, Bipan; Mukherjee, Mridula; Mukherjee, Aditya; Panikkar, K. N.; Mahajan, Sucheta (1989). India's Struggle for Independence. Penguin.

Chatterjee, Partha (1986). Nationalist Thought and the Colonial World. A Derivative Discourse. University of Minnesota Press.

Dalrymple, William (2006). The Last Mughal: The Fall of a Dynasty, Delhi, 1857. Vintage.

Duclert, Vincent (2014). La République imaginée 1870-1914. Belin.

Duras, Marguerite (1964). Le Ravissement de Lol V. Stein. Gallimard.

Duras, Marguerite (1966). Le Vice-Consul. Gallimard.

Duras, Marguerite (1971). L'Amour. Gallimard.

Duras, Marguerite (1985). La Douleur. Gallimard.

Duras, Marguerite (1987). La Vie Matérielle. Gallimard.

Heidegger, Martin (1996). Being and Time. State University of New York.

Iqbal, Allama Muhammad (2015). Reconstruction of Religious Thought in Islam. CreateSpace.

Khusrau, Amir (2010). Between Kings and Masses. Print exhibition at Jawaharlal Nehru Institute of Advanced Study, Jawaharlal Nehru University, New Delhi, 2010.

Kobuszewski, Rodolphe (2004). Marguerite Duras et la recherche du bonheur. Editions Le Manuscrit.

Krishna's Dialogue on the Soul. (Juan Mascaro, Trans.). (1962). Penguin.

Kumar, T. Jeevan (2014). Ahmed Ali: A Progressive Writer. The English Literature Journal, 1(2), 56-61. https:// doi.org/10.18853/jjell.2014.56.4.004

Marx, Karl (1984). Early Writings. Penguin.

Marx, Karl, Engels, Friedrich (2009). Selected Writings. CRW.

Maurois, André (1965). De Proust à Camus. Librairie Académique Perrin.

Mcneece, Lucy Stone (1996). Art and Politics in Duras' India Cycle. University Press of Florida.

Mukhia, Harbans (2004). The Mughals of India. Blackwell Publishing. https:/ / doi.org/ 10.1002/9780470758304

Nagarjuna (1995). The Fundamental Wisdom of the Middle Way. Oxford University Press.

Narasimhaiah, Closepet Dasappa (1968). Indian Writing in English: An Introduction. Journal of Commonwealth Literature. 3(1), 3-15. https:// doi.org/ 10.1177/002198947000500102

Nietzsche, Friedrich (1989). Beyond Good and Evil. Vintage.

Nietzsche, Friedrich (1992). Ecce Homo. Penguin. 
Knuuttila, Sirkka (2011). Fictionalising Trauma: The Aesthetics of Marguerite Duras' India Cycle. Peter Lang. https:/ / doi.org/ 10.3726/ 978-3-653-00731-2

Orlan, Mac (1972). Le Quai des Brumes. Folio.

Orwell, George (1983). 1984. Houghton Mifflin Harcourt.

Padamsee, Alex (2011). Postnational Aesthetics and the Work of Mourning in Ahmed Ali's Twilight in Delhi. Journal of Commonwealth Literature. 46(1), 27-44. https:/ / doi.org/ 10.1177/0021989410395431

Poulet, Georges (1961). Les Métamorphoses du Cercle. Flammarion.

Proust, Marcel (1954). Du côté de chez Swann. Folio.

Rahula, Walpola (1974). What the Buddha Taught. Grove Weidenfeld.

Ricoeur, Paul (2000). La Mémoire, l'histoire, l'oubli. Seuil.

Rizvi, Saiyid Athar Abbas (1997). A History of Sufism in India: Volume I. Munshiram Manoharlal Publishers.

Robinson, Neal (1999). Islam: A Concise Introduction. Georgetown University Press.

Said, W. Edward (1994). Orientalism. Vintage.

Sharma, Sunil (2006). Amir Khusrau: The Poet of Sufis and Sultans. Oneworld Publications.

Sharma, Jyotirmaya (2007). Terrifying Vision. M.S. Golwalkar, the RSS and India. Penguin. Tadié, Jean-Yves (1983). Proust, le dossier. Belfond.

Tagore, Rabindranath (2002). The Home and the World. Rupa.

Tendulkar, D.G. (1992). Mahatma Volume 3. Publications Division.

The Mahabharata. (John D. Smith, Trans.). (2009). Penguin.

Vircondelet, Alain (1996). Marguerite Duras. Vérité et Légendes. Editions du Chêne.

Vivenza, Jean-Marc (2009). Nagarjuna et la Doctrine de la Vacuité. Albin Michel.

Weil, Simone (2009). Le Ravissement de la Raison. Editions Points.

Wittgenstein, Ludwig (2008). Philosophical Investigations. Blackwell.

Wolpert, Stanley (2005). Jinnah of Pakistan. Oxford. 